Europe. The roadsides provided a palimpsest of recent European history: in the mountains of Jura the roadside grave of a French resistance fighter "fusillé par les Allemands 7/9/1944"; the quiet and peaceful Commonwealth War Graves cemetery at Castiglione dei Peopoli, belying the long, hard fought Apennine campaign; and in Switzerland the sudden realisation that here was a country in which each village did not have a war memorial.

\section{Cultural treats}

In France our relaxation was principally gastronomic, at its best in tiny restaurants ruled by an ever watchful Madame, with the classical cuisine of the Bourgogne becoming more Alpine as we neared the Swiss border. In Italy even small towns provided alfresco entertainment: cinema sotto le stelle in the village piazza; open air jazz in the Piazza del Campo in Siena; and the Bolshoi Ballet dancing in Bologna's Piazza Maggiore in tribute to the victims of the $\mathbf{1 9 8 0}$ fascist bombing at the railway station. And always there were cultural treats: the great Gothic cathedral at Sens; late Picasso in Luzern; the Thyssen-Bornemicza collection in Lugano; the polychrome marble of the cathedral in Prato; and, perhaps most moving of all, the half cleaned ceiling of the Sistine chapel-five

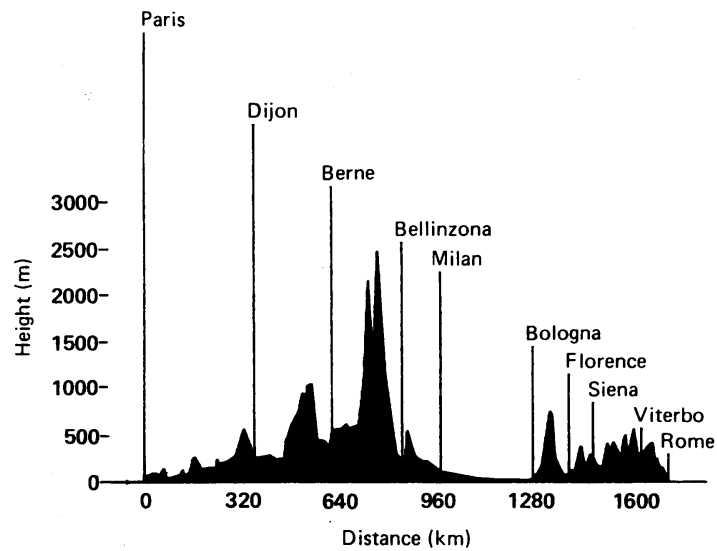

Transect of our bicycle route from Paris to Rome

centuries of candle smoke and grime removed to reveal the fresh, vivacious, almost rococo brightness that Michelangelo had intended.

The material reward of our trip was raising $£ 700$ from sponsorship for an Indian leprosy hospital. For us the most important insight was that people can still travel across whole countries and over mountain ranges on the same routes as the travellers and pilgrims of old by using muscle as the locomotive power.

\title{
Swanning in the steps of Hippocrates
}

\author{
John Walton
}

During my postwar military service in the Royal Army Medical Corps I was familiar with the definition of "a swan" - an unauthorised and often totally non-military expedition. When serving in the Territorial Army at a camp in Germany many years later the commanding officer was asked by the officer in charge of movement control about the purpose of our journey to the Berlin Military Hospital. "A swan," he said; the officer in question, with just a ghost of a smile, wrote "duty."

But in the spring of 1989 the term acquired a new meaning when I had to confess to the governing body of Green College that for the first time in my six years as warden I would miss the May meeting because of an offer I simply could not refuse-to lecture on "the legacy of Hippocrates: a history of medicine and surgery" on a Swan Hellenic cruise in the Mediterranean. When the verbal approach from my friend Harvey White was followed by a formal invitation from the company, accompanied by an outline sketch of the itinerary, it was clear that this would be a most enjoyable experience for me and my wife. And so it proved.

For those who have never travelled with Swan Hellenic, the first and most abiding impression is one of efficiency and care and attention to detail. We arrived at Gatwick to be greeted by charming representatives of the company, who, as if by magic, had arranged a speedy check in for their flock of swans. Unaccustomed to this type of tour, what a joy it was to say goodbye to our heavy baggage and not to see it again until we embarked on MV Neptune in the harbour in Venice. As soon as we landed we were taken to Padua to see the famous anatomical theatre and other treasures. We returned to Venice in time to unpack and enjoy a leisurely meal before sailing down the Giudecca canal and through the lagoon with the landmarks identified by Harvey White in the first formal lecture of our tour.

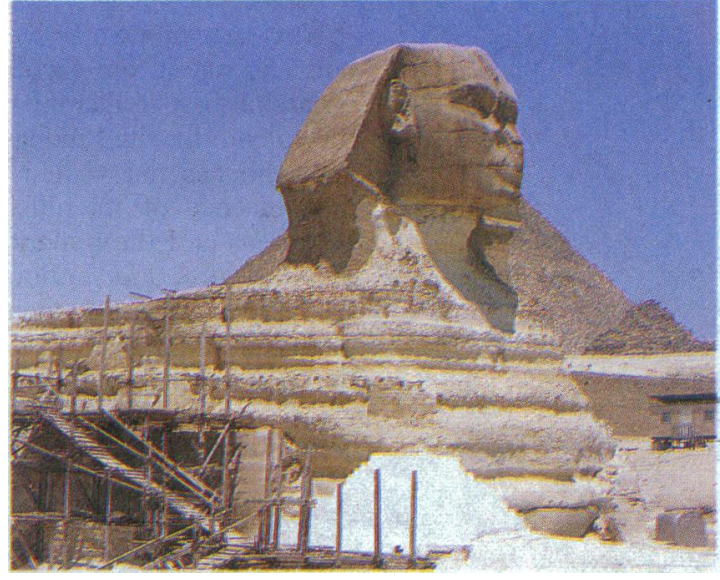

The Sphinx at Gizeh

\section{Delightful daily routine}

Our cabins were comfortable, the bars and lounge were spacious, and everyone could be seated in the main dining room. There were sun decks fore and aft with comfortable loungers and a small swimming pool, where a buffet lunch was served each day. We enjoyed sun nearly every day with only one choppy sea towards the end of the cruise, so lunch on deck became a daily and delightful ritual.

All lectures were optional and could be heard either on the deck through the excellent public address system (especially when the talk related to a sigh visible from the ship), in the main lounge, or through the loudspeakers in the cabins. There was no formal seating plan for any meal and so we were able to meet practically everyone at some time during the cruise. A family atmosphere developed as we all got to know each other. The food was of a uniformly high standard, 
served by a cheerful and courteous Greek crew, some of whom entertained us to traditional Greek music and dancing on a gala evening. But they were also sufficiently versatile to provide Turkish and Egyptian meals.

In view of the theme of the cruise many passengers were doctors and among them were many old friends. But we also made new acquaintances from different walks of life. The information made available about al aspects of the cruise was immaculate. At dinner every evening we received a carefully prepared programme of events for the following day indicating where we would be going, with times of embarkation and disembarkation, details of excursions, arrangements for meals aboard and ashore, information about currency exchanges, and the timing of lectures. A comprehensive reference library was also provided and was staffed by the lecturers' spouses. Perhaps the most extraordinary feature of our two week cruise was that we managed to travel so far and to see so much without once feeling hurried or under pressure. This was largely achieved because the ship often sailed through the night and was in port during the day.

We left Venice and arrived next day in Split to visit the ramparts and Diocletian's Palace with its fascinating undercroft. On the following day we enjoyed another walking tour through the beautiful old city of Dubrovnik and then moved on to Corfu to visit by bus the Kaiser's hideous palace (the Achilleon), adorned (if that is the appropriate word) by a huge metal statue of Achilles. Some of us enjoyed a plant and flower spotting expedition with $\mathrm{Mr}$ Alfred Evans before returning to the ship via the centre of Corfu with its royal (English) palace, now a splendid museum, and its cricket field.

\section{Magnificent Delphi}

Next morning we arrived in Itea, certainly a lovely port and one of our favourites, to enjoy a whole day excursion first to Delphi and its museum and then to the splendidly sited monastery at Ossios Loukas. No one who has not visited Delphi can appreciate the magnificence of its hillside location below Mount Parnassus and the remarkable setting of its temples, amphitheatre, and stadium. But as far as I am aware the oracle remained silent. After dinner we had a remarkable experience, a nocturnal passage between the precipitous walls of the Corinth Canal. From Piraeus next morning we visited the rather overcrowded acropolis and National Museum. But I was pleased to

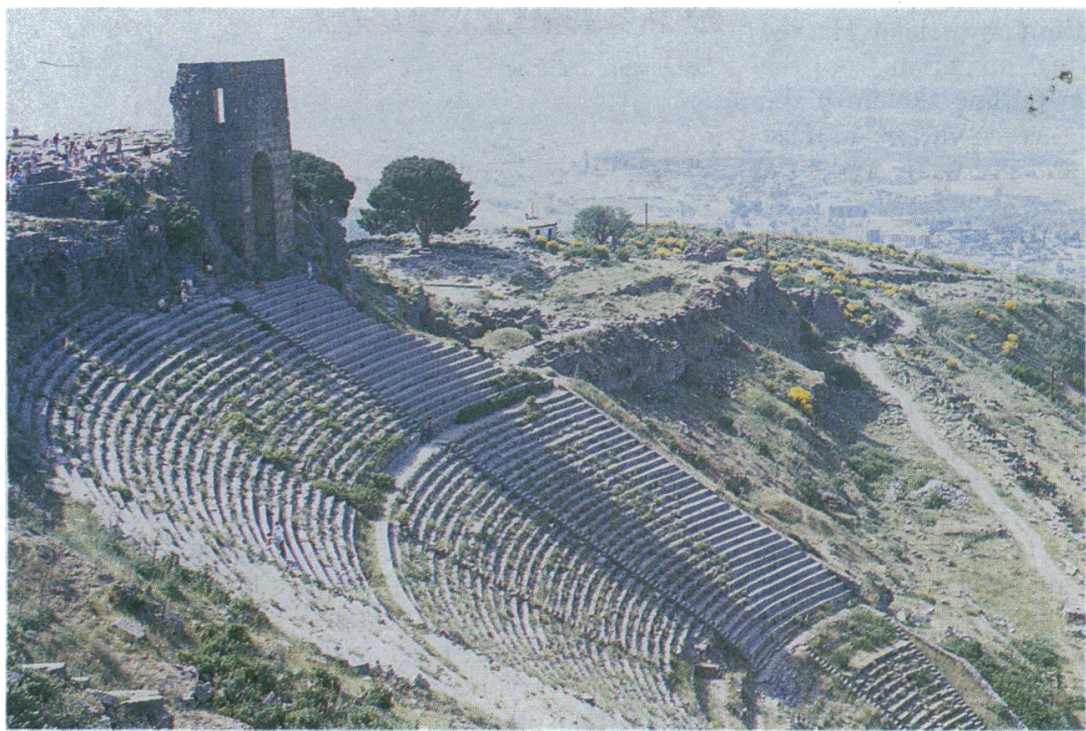

The amphitheatre on the acropolis at Pergamum see from the heights of the acropolis the Tower of the Winds standing proudly in the Agora. The 1794 tower of the Radcliffe Observatory in Oxford, which now houses Green College, was modelled on that splendid building of ancient Athens.

Yet again we sailed at night, arriving next morning at Nauplion, where alternatives were offered: a trip to Epidaurus to see the amphitheatre and museum or to Mycenae to see the lion gate, the beehive tombs, and the superbly sited acropolis. Then it was back to the ship to sail for Crete. On arrival at Heraklion next morning we visited the Minoan archaeological site of Knossos and its museum. Opinions vary about the quality and taste of the restoration carried out by $\mathrm{Sir}$ Arthur Evans. At first I found the artificiality of some of the dark red pillars and reconstructed walls disturbing, but later I concluded that the resultant effect enlivened the scene.

Much of the next day was spent at sea but we arrived at Alexandria in the early evening and visited the Kait Bey Citadel, the Mosque of Abul Abbas, the monument to the unknown soldier, and Pompey's Pillar. Most of us then took an all day trip to Cairo, enjoying refreshment at Mena House (of military memory) before visiting the pyramids at Gizeh and the splendidly preserved Boat of Cheops in its new museum. We moved on to the Cairo Museum to see the Tutankhamun relics, which seemed even more magnificent than I remember them from my first visit when serving in the canal zone in the army in 1948.

After another night and day at sea we arrived in Rhodes and spent a few hours next day on a walking tour through the Marine Gate into the old city, visiting the Hospital of the Knights, the Street of the Knights, and the Palace of the Grand Master. What a contrast there was between the early morning grandeur, solemnity, and uniformity of the lovely old stone buildings and the garish modernity of the shops and restaurants which had opened before we returned. Over lunch we sailed to Kos, visiting the asclepieion with its panoramic views and the famous plane tree in the main square under which it is alleged that Hippocrates once taught. Our expert botanist believed that at the very most the tree could not possibly be more than 500 years old. Nevertheless, the ambience was almost eerily evocative; it set the scene for our arrival next morning at Dikili in Turkey, where we visited yet another magnificently sited acropolis on the hill at Pergamum and later the asclepieion before returning to the ship. The shades of Galen were all around us.

\section{Mount Athos out of the mist}

Next morning as the sun slowly dispersed the mist we saw faintly at first, later in all its grandeur, the outline of Mount Athos on its narrow peninsula. We then sailed close in shore and had an excellent view of the many monasteries and sketes of varied architectural style, some perched precariously on the mountainside, others close to the shore, some tiny, and some vast. Many of the women on board were not impressed by the fact that no woman is allowed on the peninsula and that even female animals are banned. We wondered how long this closed monastic settlement would survive; a population of over 20000 has now shrunk to about 2000 permanent residents, though their numbers are swelled by the many male visitors who arrive for study, relaxation, or contemplation throughout the year. The cruise ended in Thessaloniki with a final visit to another splendid archaeological museum before the flight home.

But what of the lectures? We were fortunate. $\mathrm{Mr}$ Colin Badcock, a housemaster from Winchester and a noted classicist with a delightful if at times mordant 


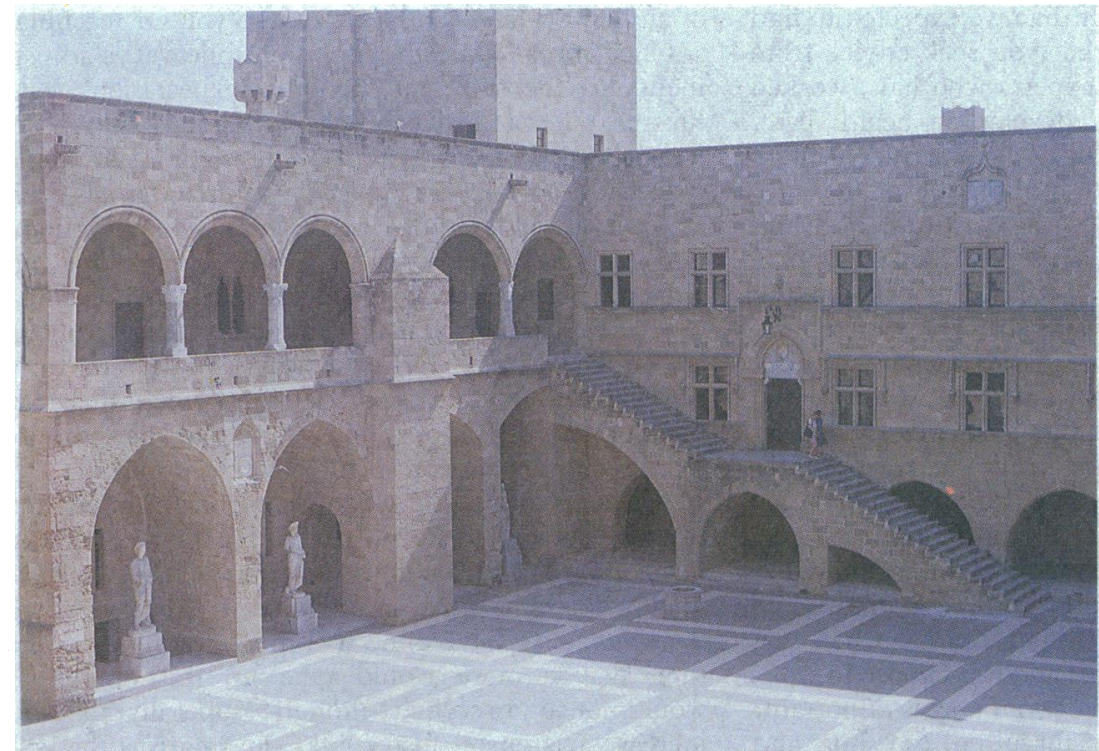

The castle of the Knights of St Fohn, Rhodes and racy wit, kept us entertained and edified with his many talks on topics such as "oracles and healing," "Crete and its palaces," "the colossus of Rhodes," and "the Knights of St John and the Crusades." The Reverend Dr Philip Edgcumbe Hughes discussed "the cult of Asclepieios" and "the church and medicine throughout the ages," and also described the different monasteries and sketes on the Mount Athos peninsula. Dr Barbara Watterson, an Egyptologist from Liverpool and a lively lady, taught us about "the legacy of Imhotep," "the Egyptian way of death," and many other fascinating topics, while Mr Alfred Evans, our twinkling Scottish botanist from the Royal Botanical Gardens in Edinburgh, not only shared with us some hilarious expeditions of plant spotting in the quiet and wilder countryside but also taught us about herbs and medicine.

And what of our medical colleagues? I certainly shall not forget Surgeon Vice Admiral Sir James Watt's lectures on "medicine at sea," Professor James Robinson on "Hippocrates to Galen," Mr Harvey White on "surgery in perspective," and Sir Christopher Booth on "patients, plagues, and pestilence across Europe." And several passengers, too, contributed ten minute vignettes about various historical passions or hobby horses.

I prefer to draw a veil over my own contributions, but as I write in the library once occupied by Sir William Osler I reflect on the truism that so much of what doctors do today and so many of the precepts and principles on which the proper practice of modern day medicine depends are based on the examples and discoveries of our forebears.

My "swan" in the steps of Hippocrates was a delight from beginning to end. It was a memorable experience which brought to life much of what I knew and did not know about ancient Greek and Egyptian medicine.

\title{
"Been to Africa"
}

\author{
Alison Fiander, David Hughes
}

As the end of our contracts working in a rural hospital in Africa approaches we are asking ourselves questions. Has it been worth it? What have we learnt? Should we recommend it to others?

In many specialties budding registrars feel the necessity to enter a research post or to travel abroad, notably to the United States - the "been to America" syndrome. Until they do their future paths may be blocked. The rationale behind such a period of research is said to be to sharpen the mind and to cultivate a sense of inquiry and critique. Much of the actual research is neither earth shattering nor fulfilling but rather represents clinicians marking time. Travelling to the United States is not always the best alternative either; finding a suitable job may be difficult, defensive medicine may prevent you from doing as much as originally expected, and other frustrations may arise. So what alternatives are left? Might time spent working in a developing country prove worth while? We think so.

The main drawback of our working in such relative isolation is that our practice is unsupervised. The medicine is often very different from that encountered at home. The general standards of medical and nursing care are low, facilities and infrastructure poor, and the size of the problem enormous. We have had periods of feeling alone and helpless, knowing that under different circumstances we might have saved the person before us - life seems cheap at times. We have had to change our attitudes and expectations. Inevitably mistakes have been made and patients have suffered; the responsibility weighs heavily at such times. Poor motivation among the staff, lack of essential supplies, and suffering our own share of tropical diseases have created added frustrations. We know that some will level the argument of unsuper- vised work and inappropriate medicine, but on the other hand we have benefited in many ways: we have had to rely on and improve our basic skills in examination and have grown more confident and self reliant in our judgments. In addition, we have had to be careful to justify the use of limited resources, and within these limits our technical abilities have improved. Seeing the complications of delayed medical care, rarely seen in Europe today, has brought to life for us the benefits of modern health care, raised patient expectation, and good transportation. Not only have we been tested clinically but we have also had to develop management and administrative skills. We have read with interest the discussions in the $B M \mathcal{F}$ concerning the government's white paper-we have had no option but to act as managers and to be aware of costs; we soon learnt that there is no medicine without logistical support. There have been great possibilities for teaching and introducing small changes, though it has paid to be realistic and not to expect to change the world. Added to all this has been the rich experience of seeing patients recover, receiving their gratitude, seeing their smiling faces despite their extreme poverty and their quiet suffering. We have met great acceptance and friendship from the nurses, many of whom have taught us valuable lessons both medically and culturally.

\section{Don't delay ... plan today}

Overall, the experience has been a positive one and we feel that it has broadened our outlook and that we have matured. If you are tempted we would certainly encourage you to consider a similar period and would like to offer some words of advice. Don't leave it too late-one to two years' planning may be required. We 